Dansk Ultralyddiagnostisk Selskab

\title{
EUROSON 2018 Poznan
}

The EUROSON Congress of EFSUMB (European Federation of Societies in Ultrasound in Medicine and Biology) blev I 2018 afholdt i den polske by Poznan. Indbyggertallet i Poznan er på ca. 540.000, og det er Polens ældste by. På slaget 12 hver dag, er der mulighed for at se kirkeklokken unikke mekaniske ur, hvor 2 geder slår hovederne mod hinanden.

I alt deltog ca. 800i kongressen med mange forskellige uddannelsesbaggrunde, og der deltog ca. 12 danskere fra Vejle, København, Herlev og Aarhus. Mange af de danske deltagere var aktive med foredrag og posters. På industriudstillingen var der stor industri udstilling med bl. a. ultralydsfantomer, div. ultralyds maskiner, transducerer, styr og andet lækkert udstyr.

Kristoffer Lindskov Hansen afholdte Hans Henrik Holm lektionen med titlen „Vector Velocity Imaging - a New Application in Medical Ultrasound“. Kristoffer Lindskov har i øvrigt lige indleveret en doktordisputats om dette emne.

Jonathan Carlsen, Rigshospitalet holdt foredraget „Elastography of the breast: When should we assess tumour stiffness". I Europa rammes ca. hver 4 kvinde af brystkræft, og i dag ses en 5 års overlevelse på op til $80 \%$. Jonathan gennemgik grundigt BI-RADS, Visual Score, og sensitiviten og specifiteten ved henholdsvis elastografi og b-mode ultralyd. Både sensiviteten og specifiteten forbedres ved kombination af b-mode og elastografi.

Christian Nolsøe, Herlev Hospital, holdt foredraget „Interventional Ultrasound Pioneers in Europe. The Short version“. Her fortalte han om Dansk ultralyds historie og pionererne indenfor ultralyds intervention.

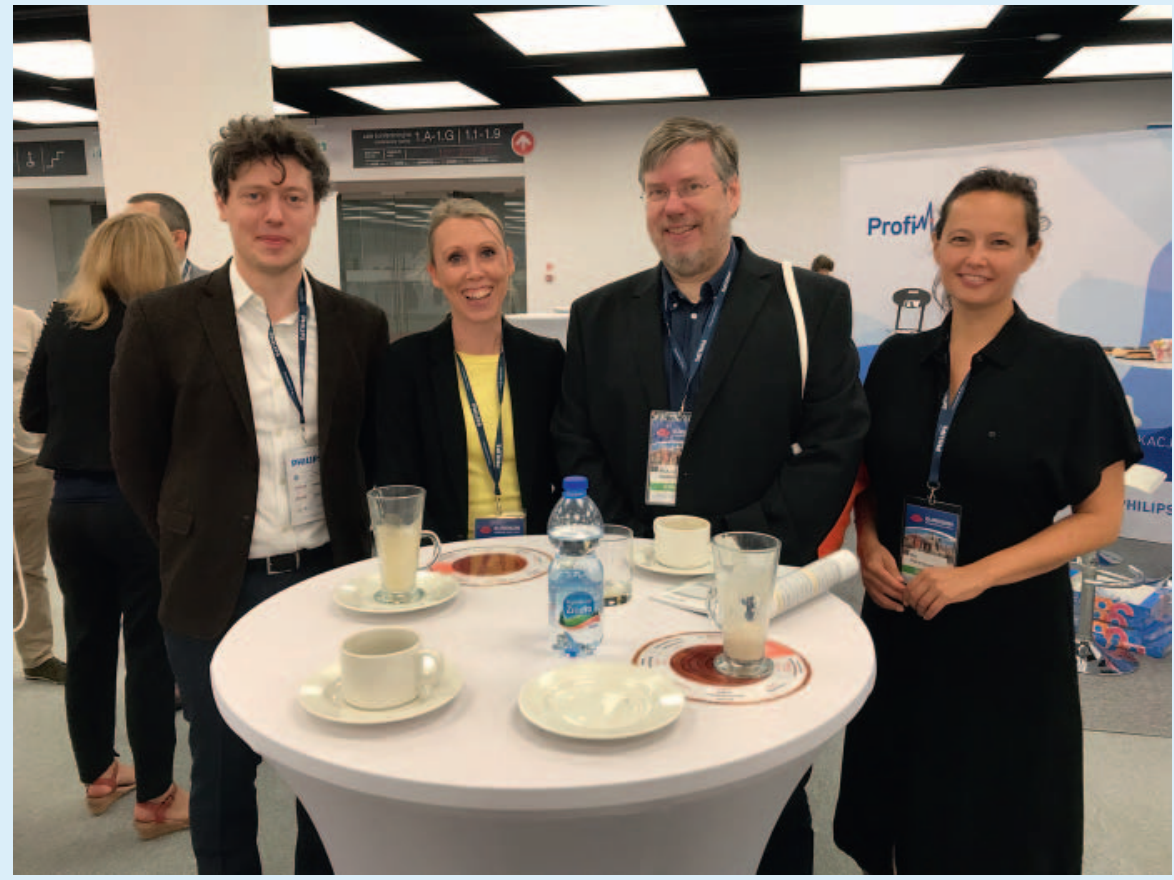

God stemning i kaffepausen blandt foredragsholdere og poster-bidragsydere.

Professor Michael Bachmann, Rigshospitalet, var chairman for sessionen „The use of hand held ultrasound devices", hvor han også fremlagde en spændende SWOT analyse ifht. brugen af håndholdt ultralyd. Jonathan Carlsen, Rigshospitalet, havde efterfølgende en session omkring abdominal håndholdt ultralyd, herunder for og imod, og hvad fremtiden bringer. Mia Østergaard, Rigshospitalet, fremlagde tilslut et spændende studie hun har arbejdet med, hvor der benyttes håndholdt ultralyd i pædiatri.

Malene Roland, Vejle Sygehus, \& Sara S. Bak, Aarhus, præsenterede begge til poster sessionen fredag, som i år foregik over 2 dage.

Der var også mange spændende foredrag, og en større poster talk.

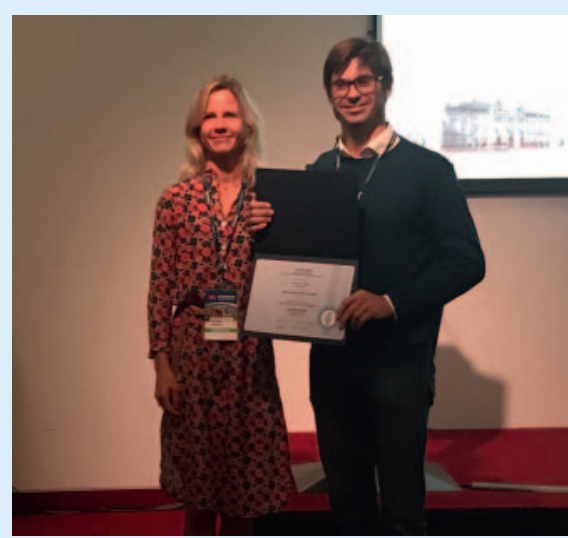

Kristoffer Lindskov Hansen modtager efter Hans Henrik Holm Lektionen EFSUMBdiplom fra Caroline Ewertsen.

Håber vi ses i 2019i Granada, Spanien, det er bestemt en oplevelse værd.

Malene Roland 